\title{
Inność, którą trzeba chronić. O empatii zbudowanej na dystansie
}

Empatia to pojęcie, które na naszych oczach zyskuje niesłychaną popularność. Posługują się nim psychologowie, socjologowie, filozofowie, antropologowie, historiozofowie, a nawet politycy. Przede wszystkim jednak kategoria empatii znalazła swoje miejsce w literaturoznawstwie, gdzie ze zmiennym natężeniem obecna jest od końca wieku XIX, choć rodzące się wówczas formy narracji służące odzwierciedlaniu cudzej świadomości - technika punktów widzenia, narracja personalna, a także stosowana już w romantycznej powieści poetyckiej mowa pozornie zależna - zyskały miano empatycznych dopiero ex post. Książkę Krystyny Pietrych Co poezji po bólu. Empatyczne przestrzenie lektu$r y^{\Gamma}$ nazwać można swoistym podsumowaniem ponadstuletniej historii omawianej tu kategorii w humanistyce. Obserwujemy, jak historia ta zatoczyła koło, a jej punkt dojścia okazuje się fascynująco odmienny od punktu wyjścia.

Samo słowo najpierw pojawiło się w Husserlowskiej fenomenologii jako die Einfüblung ${ }^{2}$, a na gruncie personalizmu fenomenologicznego rozwinęła jego rozumienie uczennica Edmunda Husserla - Edyta Stein3. Potem na grunt psychologii przeniósł je Theodor Lipps, uznając wczucie za jedną z trzech - obok obserwacji siebie i obserwacji otoczenia - płaszczyzn poznania ${ }^{4}$.

I Zob. K. Pietrych, Co poezji po bólu. Empatyczne przestrzenie lektury, Łódź 2009. Przy kolejnych odwołaniach do tej pracy podaję w tekście głównym paginację zapisaną w nawiasie.

${ }_{2}$ Zob. E. Husserl, Zagadnienie wczucia, przeł. D. Gierulanka, komentarz J. Tischer, „Znak” 1974, nr 3, s. 319-327.

3 Zob. E. Stein, O zagadnieniu wczucia, przeł. D. Gierulanka, F. Gierula, Kraków 1988. Zob. też P. Biela, Einfüblungjako dialogiczność personalizmu fenomenologicznego Edith Stein, „Czasopismo Filozoficzne” 2009, nr 4/5.

4 Zob. M.H. Davis, Empatia. O umiejętności współodczuwania, przeł. J. Kubiak, Gdańsk 2001. 
Pojęciem posługiwał się także w swej filozofii Wilhelm Dilthey5, który połączył je z kategorią doświadczenia. Z kolei na naszym rodzimym gruncie empatia dominowała jako metoda krytyczna badaczy młodopolskich ${ }^{6}$ : wiązała się $\mathrm{z}$ podmiotowym wymiarem obcowania z dziełem literackim, czyli ze stosowanymi przez krytykę literacką przełomu wieków technikami utożsamienia i identyfikacji z fikcyjnym bohaterem, a także z autorem. Stanowiła zatem symbiozę przeżycia estetycznego i psychologii.

Ta tęsknota za jednością, której patronowała między innymi filozofia życia, około 1910 r. ustąpiła miejsca postawie zdystansowanego oglądu przedmiotu badań, wiążącej się „ze zdecydowanym odejściem od wymogu odbioru emocjonalnego" 7 . Postawa ta w pełni ujawniła się w modelu strukturalistycznym badań literackich, w którym dzieło zyskało autonomię, natomiast badacz, zachowując obiektywizm i pełną separację od przedmiotu badań, koncentrował się na językowych właściwościach utworu. W ten sposób nowoczesne literaturoznawstwo zaczęło się rozwijać pod znakiem naukowości. Badacz uosabiać miał odcieleśniony kartezjański umysł, stosujący racjonalne narzędzia poznania. Dystans - jak wskazywał w znanym eseju José Ortega y Gasset stawał się warunkiem i sposobem istnienia znaczącej części sztuki nowoczesnej, która swój przedmiot estetyczny budowała na niezaangażowanym emocjonalnie oglądzie ${ }^{8}$. Dodatnio dystans jako reakcję na kryzys epistemologiczny wartościował też Wilhelm Worringer, dostrzegający w empatyczności niewiarygodną, bo niemożliwą i upraszczającą, metodę oswajania świata9.

Dziś - po przełomie poststrukturalistycznym, a także po zwrocie kulturowym i etycznym, które ujawniły indywidualny, idiomatyczny wymiar tekstu jako tego, co inne i nieredukowalne do tego samego - przyszedł czas rehabilitacji osobistej, zaangażowanej aksjologicznie lektury ${ }^{\text {Io }}$. O ile młodopolskie współodczuwanie często okazywało się sprzeczne z zachowaniem dystan-

5 Zob. S. Skwarczyńska, Od przełomu antypozytywistycznego do roku 1945, w: Teoria badań literackich za granica, t. 2, cz. 1, Kraków 1974, s. 22. Historię kategorii empatii w XX w. wyczerpująco prezentuje A. Łebkowska, Empatia. O literackich narracjach przełomu XX i XXI wieku, Kraków 2008, s. 189-219.

${ }^{6}$ Zjawisko to opisał M. Głowiński, Ekspresja i empatia. Studia o młodopolskiej krytyce literackiej, Kraków 1997.

7 A. Łebkowska, op.cit., s. 202.

${ }^{8}$ Zob. J. Ortega y Gasset, Dehumanizacja sztuki i inne eseje, przeł. P. Niklewicz, wybór, wstęp S. Cichowicz, Warszawa 1980.

9 O książce W. Worringera, Abstraction and Emphathy. A Contribution to the Psychology of Style (przeł. M. Bullock, London 1953) pisze Anna Łebkowska. Zob. A. Łebkowska, op.cit., s. 12.

ro $\mathrm{W}$ ten sposób empatia ponownie znajduje się w centrum uwagi jako zjawisko filozoficzne, antropologiczno-kulturowe i psychologiczne oraz staje się kategorią transdyscyplinarną, wchodzącą w obszar zainteresowań antropologii 
su, o tyle towarzyszące formowaniu nowoczesnej podmiotowości poczucie wyobcowania wzmocniło świadomość obecności wielorakich, nieusuwalnych zapośredniczeń między autorem, dziełem i czytelnikiem, które powodują „konieczność utrzymania raczej dystansu aniżeli stanu pełnego przenikania" ${ }^{\text {II }}$.

Empatia nie stanowi już sposobu docierania do wiedzy o drugim, nie jest narzędziem literackiej epistemologii opartej na wierze w bezpośredniość komunikacji na głębokim, pozawerbalnym poziomie. Nie jest to znane z doświadczeń Młodej Polski „wchodzenie w cudzą skórę", mające doprowadzić do pełnej identyfikacji, równoznacznej ze zniweczeniem inności drugiego. Empatia z obszaru psychologii i epistemologii przemieściła się na teren aksjologii i etyki oraz estetyki. Empatyczna lektura przeksztalciła się w obcowanie z tekstem, który nigdy do końca zrozumieć ani oswoić się nie da. W postawie empatii liczy się dziś zatem nie tyle możliwość odtworzenia w sobie cudzych doświadczeń, co etyczna konieczność podejmowania działań prowadzących do ochrony tego, co inne, co wymyka się uogólnieniu, uniwersalizacji, a także utekstowieniu.

Obserwowany w literaturoznawstwie od 30 lat wzrost zainteresowania empatią dotyczył sytuacji bohatera, sposobów konstruowania narracji, wreszcie też retoryki figur poetyckich albo wewnątrzliterackich poziomów komunikacji, albo ich oddziaływania na czytelnika ${ }^{\mathrm{I}}$. Rzadko natomiast mieliśmy do czynienia z pracami naukowymi, których autorzy sami przyjmowali postawę empatycznie zaangażowanych, odwołując się do swoich emocji i uczuć. Literaturoznawca wciąż bowiem pozostawał przede wszystkim znawcą. Perspektywę taką najwcześniej otworzyły badania hermeneutyczne, które odegrały istotną rolę w ewolucji nurtu osobistej, rozumiejącej lektury ${ }^{\mathrm{I}}$. Zasada jawnie subiektywnego czytania konsekwentnie realizowana była do tej pory przede wszystkim przez krytyczki feministyczne, które z osobistego, autobiograficznego podejścia do czytanych tekstów uczyniły jeden $\mathrm{z}$ konstytutywnych elementów écriture féminine.

literatury i antropologii literackiej. Zob. A. Łebkowska, Między antropologia literatury $i$ antropologia literacka, w: op.cit., s. 221-239.

II Ibidem, s. 30 .

I2 Zob. J. Płuciennik, Literackie identyfikacjei oddźzwięki. Poetyka a empatia, Łódź 2004. Autor zajmuje się kognitywnymi aspektami poetyki, koncentrując się na opisie retorycznych mechanizmów rządzących reakcjami empatycznymi i identyfikacyjnymi czytelnika. Również A. Łebkowska sama nie posługuje się empatią jako metodą badania, skupiając się na charakterystyce różnych płaszczyzn jej przejawów w obrębie nowej prozy.

I3 Na rangę hermeneutyki zwrócił mi uwagę prof. dr hab. Michał Kuziak. Słusznie upomniał się też o pamięć o prekursorskich pracach J.M. Rymkiewicza, zwłaszcza pisanych od końca lat 70. 
Dlatego książka Pietrych Co poezji po bólu... to w polskim literaturoznawstwie dzieło pod względem metody niezwykłe i prekursorskie. Badaczka wielokrotnie odwołuje się do publikowanych wcześniej fragmentów rozprawy Anny Łebkowskiej, czerpie inspiracje z jej poglądów i uwag. To, co robi, stanowi jednak dokonanie $w$ pełni samodzielne. Podejmuje się mianowicie opisania z pozycji krytyki empatycznej fenomenu doświadczania bólu i uobecniania tego doświadczenia w wierszu. Pytanie: „Co poezji po bólu?”, wyjęte z wiersza Aleksandra Wata, staje się nadrzędnym problemem towarzyszącym lekturom badaczki, która $\mathrm{w}$ poezji siedmiorga poetów szuka rozwiązań takich między innymi kwestii:

Jak uczynić doświadczenie choroby i cierpienia doświadczeniem „mówionym”, „pisanym”? Jak sprostać tak niezbędnej i jednocześnie tak trudnej potrzebie komunikacji? Jak oddać skrajne doświadczenie ciała? Czy da się je przełożyć na język? Jak zapisać doświadczenie cierpiącego ciała poddanego chorobie? Jak zapisać doświadczenie własnego ciała w bólowej opresji? Czy takiemu wyzwaniu może podołać sztuka? (s. 8)

Podobne zagadnienia służą rekonstrukcji kolejnych etapów formowania się literackiego świadectwa cierpienia. Dają przy tym wyraz zasadniczej wątpliwości dotykającej nie tylko poetę szukającego środków wyrazu dla własnego cierpienia, lecz również czytelnika stykającego się $\mathrm{w}$ wierszu z zapisem rejestrującym cierpienie autora: w jakiej relacji (jeśli w ogóle istnieje) znajdują się doświadczenie fizycznego bólu oraz język poezji mający to doświadczenie wyrazić? W pytaniu zawarte jest założenie autorki, która przyjmuje, że przeżywaniu cierpienia towarzyszy potrzeba ekspresji oraz że doświadczenie cielesne stanowi ważny wymiar zajmującej ją poezji. Znaczy to, iż odsłonięcie niejawnych (jak u Zbigniewa Herberta czy Janusza Szubera), lub wręcz świadomie maskowanych (jak u Stanisława Barańczaka, a także, w inny sposób, u Juliana Przybosia) biograficznych, intymnych elementów genezy wierszy wydobywanych przez badaczkę z pozapoetyckich autokomentarzy, źródeł biograficznych itp., nie tylko rzuca nowe światło na te teksty, stając się ważnym tropem interpretacyjnym, ale też - a nawet przede wszystkim w znaczący sposób wpływa na czytelnika-badacza: obliguje go do przekroczenia ram naukowej anonimowości, do udzielenia równie osobistej odpowiedzi na wezwanie cierpiącego człowieka, który stoi za wierszem. To przekonanie zakreśla metodologiczny horyzont badań, wytyczając perspektywę empatycznej lektury. 
Rezygnacja $\mathrm{z}$ badawczego dystansu na rzecz postawy ludzkiego współczucia budzić może obawy o uleganie pokusie przenoszenia własnych emocji na podmiot autorski w wierszu. Na szczęście Pietrych - świadoma ryzyka wiążącego się z opuszczeniem uprzywilejowanej pozycji badacza literaturoznawcy nie rezygnuje $\mathrm{z}$ metajęzyka, który stanowi podstawowe narzędzie opisu komentowanych utworów. Tym metajęzykiem jest przede wszystkim poetyka, zamocowana w strukturalistycznych ramach (choć podszyta dekonstrukcją), pozwalająca ująć żywioł własnych emocji w nurt filologicznego namysłu nad tekstem, a także filozofia, o której powiem za chwilę. W ten sposób empatia nie staje się metodą identyfikacji z cierpiącym autorem i światem jego wartości, lecz złożonym, świadomym własnych komplikacji sposobem prezentacji poetyckiego radzenia sobie $\mathrm{z}$ bólem.

Zdając sobie sprawę z nieprzekładalności bólu na jakiekolwiek językowe środki wyrazu, badaczka wskazuje na trzy podstawowe kwestie związane z problematyką jego przedstawiania $\mathrm{w}$ poezji. Są to: doświadczenie, ciało oraz reprezentacja. $\mathrm{Z}$ decyzji związanych z tymi zagadnieniami wynika przyjęty przez nią sposób czytania, dlatego warto przyjrzeć się, w jaki sposób przygotowuje sobie narzędzia.

Pietrych zwięźle rekonstruuje sytuację współczesnego pojęcia doświadczenia, łącząc je - co zrozumiałe $-\mathrm{z}$ kategorią ciała. Doświadczenie jest kategorią, która odzyskała swoje miejsce w humanistyce po długim okresie tryumfu abstrakcyjnego rozumu i wiedzy teoretycznej. Badaczka odwołuje się do myśli Diltheyowsko-Deweyowskiej, czyli hermeneutyczno-pragmatycznej koncepcji doświadczenia. Oba stanowiska godzić ma Richard Shusterman - wywodzący się ze szkoły Johna Deweya pragmatysta, twórca kategorii somatoestetyki, która przywołuje pierwotny źródłosłów estetyki: aestesis, będącej przeżyciem zmysłowym, nie intelektualnym. Zamiast dominującego w nowoczesnej refleksji spojrzenia teoretycznego, uprzywilejowującego wzrok jako zmysł poznania, a zarazem figurę racjonalności odcieleśnionego rozumu, pojawia się kategoria doświadczenia cielesnego, które „uniwersalności, powszechności i racjonalności poznania rozumowego” przeciwstawia „bezpośredniość, konkretność, zmysłowość, jednostkowość" (s. 14).

Zaniedbane przez estetykę i nowoczesną filozofię ciało powraca w refleksji Shustermana jako cielesność ${ }^{1} 4$ będąca centrum dzia-

I4 Trafne wydaje się tu również określenie „mięsność” użyte przez J. Brach-Czainę w książce Szczeliny istnienia, Warszawa 1992. 
łania i doświadczania - nieodłącznym od psyche, stanowiącym z nią jedność. Częścią tak rozumianego doświadczenia jest język, który „konstytuuje doświadczenie i czyni je świadomościowo pochwytnym" (s. 13). To pozwala autorce mówić o poezji jako piśmie bólu, eksponującym - za Mauricem Merleau-Pontym, Rolandem Barthes'em, Georges'em Bataille'em, Jacques'em Lacanem, Gilles'em Deleuzem, Jean-François Lyotardem i Jacques'em Derridą - nierozłączność języka i ciała.

Wśród filozoficznych patronów swej postawy badaczka wskazuje jako najważniejsze trzy nazwiska: Ricoeura, MerleauPonty'ego oraz Lévinasa. Pierwszy pojawia się z racji swej hermeneutycznej koncepcji tożsamości ,ja” jako Innego: zapośredniczonego w tekstach kultury poznawania siebie i poznawania innego. Pogląd ten wzmacnia perspektywa ciała fenomenologicznego ${ }^{\mathrm{I}}$ Merleau-Ponty'ego, który podkreśla cielesność aktu lektury, przekształcającą literacką komunikację w przestrzeń spotkania: odbiorca nie tylko deszyfruje tekst, lecz jest zobligowany do podjęcia próby dotarcia do „słowa-gestu-ekspresjiinnego" (s. 29), to zaś możliwe jest tylko przez zapośredniczenia. W naturalny sposób uruchomiony zostaje kontekst filozofii Emmanuela Lévinasa i jego pojęcia Innego jako absolutnie innego, który będąc kimś niepojętym, wzywa zarazem do etycznej odpowiedzialności ${ }^{16}$.

I5 Ciało potraktowane zostało przez autorkę - za Johnem D. Caputo jako flesh. W odróżnieniu od body, będącego centrum zmysłów nakierowanych przede wszystkim na zewnątrz, flesh to ciało „w sobie zamknięte”, ciało dotknięte procesem niszczenia, gnicia, rozpadu, cierpienia i śmierci. Doświadczenie „mięsności” ciała pozbawia je nieczułości i niewrażliwości charakteryzującej body. Będąc bezbronne, jest jednocześnie wystawione na zranienie, zmiażdżenie, rozszarpanie. Ciało właśnie $\mathrm{w}$ tym drugim znaczeniu - będące u Johna Caputo ciałem budzącym w innym podmiocie przede wszystkim agresję, u Kristevy grozę i wstręt, a u Lévinasa odpowiedzialność - znajduje się w centrum zainteresowania badaczki. Ponieważ jednak ciało jest nieme, nie może stać się ono $\mathrm{w}$ takiej postaci przedmiotem przedstawienia. W sztuce pojawia się ciało utekstowione, przemienione, zmediatyzowane. Oczywiście, wciąż aktualne pozostaje pytanie: „do jakiego stopnia możliwa jest tekstualizacja somatycznego doświadczenia?” (s. 18). Jest to zatem pytanie o możliwość reprezentacji w literaturze "granicznego przypadku bólowego doświadczenia egzystencjalnego" (s. 18).

I6 Warto $\mathrm{w}$ tym miejscu podkreślić różnicę między etyczną perspektywą Lévinasa i wywodzącą się z Nietzscheańskich i psychoanalitycznych źródeł wizją podmiotu rysowaną przez Caputo. Obaj wprawdzie uważają, że flesh Innego nigdy nie jest neutralny, lecz o ile dla Lévinasa pierwszym impulsem, jaki wywołuje Inny we mnie, jest odpowiedzialność - to według Caputo „ja” jest ze swej natury agresywne i reakcja, jaką wywołuje w nim cudza słabość (flesh), jest przede wszystkim reakcją agresji. Jeśli zatem kontakt z flesh drugiego w jakiś niezwykły, paradoksalny sposób prowadzi do przemiany mojego ciała (body) we flesh - jest to zjawisko nieracjonalne i nieoczywiste. Moje zobowiązanie 
Tak zarysowany horyzont personalistycznej, hermeneutycznej lektury tworzy przestrzeń spotkania, które odbywa się za pośrednictwem tekstu poetyckiego. Tekst ten traktowany jest jednak nie jako nieprzenikniona, autoreferencjalna gęstwa niezależna od swego autora, lecz jako szczególny tekst wezwanie, domagający się w imię poszanowania dla cudzej inności odpowiedzi etycznej - bezpośrednio zaangażowanej w lekturę. Pietrych, dobierając bohaterów swej książki według klucza osobistej sympatii i osobistego współczucia, traktuje każdy akt lektury jako spotkanie z niepowtarzalną i nieredukowalną innością, podczas którego sama ma prawo odsłonić własne uczucia towarzyszące odbiorowi. Trzeba przyznać, że jest to postawa niebezpieczna, obarczona ryzykiem dowolności, a przynajmniej nieweryfikowalnej subiektywności. Autorce zresztą, co pokażę, nie udało się uniknąć wpadnięcia w pułapkę tak definiowanej empatyczności, choć ona sama słusznie odżegnuje się od identyfikacji z cierpieniem swych bohaterów.

Oczywiście to, że wyszła poza sztywne reguły naukowości, idąc drogą wytyczoną przez krytyczki feministyczne, dla których akt lektury wiąże się z zaangażowaniem nie tylko intelektualnym, lecz także emocjonalnym, osobistym (czytanie ciałem jako odpowiedź na pisanie ciałem) - jest wyrazem zjawiska coraz częściej spotykanego wśród literaturoznawców. Wobec perspektywy „słabej profesjonalizacji” ${ }^{{ }_{7}}$ literaturoznawstwa jako dyscypliny nieuniknione było rozluźnienie rygorów naukowości. Scjentologiczny obiektywizm, całkowita anonimowość badacza prezentującego niezależny od osobistych przekonań autora, „naukowy" projekt - to cechy, które nie wydają się dziś bezstronne, budzą nawet sprzeciw swą kategorycznością, sugerującą prawdziwościowy wymiar prezentowanych racji. Tymczasem narracja literaturoznawcza jest efektem przyjętych założeń, a nade

względem drugiego, tkliwość i wrażliwość mogą narodzić się pod wpływem bezbronności drugiego. Flesh Innego nie jest jednak zobowiązaniem etycznym, logicznym i naturalnym. Według Caputo ekonomia zobowiązania, bycia wezwanym przez Innego jest czymś szalonym, czymś, co odbywa się wbrew strukturze „ja”. Czynienie z cudzego dobra - dobra własnego jest nielogiczne. Zob. J.D. Caputo, Against etbics: contributions to a poetics of obligation with constant reference to deconstruction, Bloomington 1993. Dlatego też K. Pietrych bierze z koncepcji Caputo jedynie zjawisko flesh, by obudować je personalistyczną, etyczną i empatyczną filozofią Lévinasa, z którym Caputo polemizuje. Powody, dla których badaczka nie wspomina o antytetycznym wymiarze filozofii Caputo, postaram się uchwycić w dalszym wywodzie.

${ }_{17}$ Zob. R. Nycz, Wprowadzenie. Kulturowa natura, staby profesjonalizm. Kilka uwag o przedmiocie poznania literackiego i statusie dyskursu literaturoznawczego, w: Kulturowa teoria literatury. Gtówne pojęcia i problemy, red. M.P. Markowski, R. Nycz, Kraków 2006, s. 5-40. 
wszystko poglądów, wrażliwości i biograficznego doświadczenia badacza. Można fakty te przemilczeć lub uczynić z nich jedno $\mathrm{z}$ najistotniejszych metodologicznych przeświadczeń. Drugie podejście reprezentuje omawiana rozprawa, której autorka sama występuje w pozycji czytelnika jako Innego - tego, który słabości nadawcy przeciwstawia własną słabość i stara się w miarę własnych kompetencji zrozumieć inność drugiego. Pozwala, by czytanie stało się dla niej zarówno aktem mniej lub bardziej osobistej lektury, jak i przeżyciem, które pozostawia w niej samej trwały ślad.

Czy takie empatyczne, osobiste czytanie jest przywilejem czytelnika kobiety? Tego nie wiem. Wydaje mi się natomiast, że feministki nie miałyby $\mathrm{w}$ autorce Co poezji po bólu... zbyt wielkiego wsparcia. Przede wszystkim dlatego, że nie pragnie ona niczego nikomu udowadniać, nie przyjmuje głęboko przemyślanej strategii prywatności i intymności, by wydobyć to, co ukryte i wyparte przez oficjalny dyskurs, lecz bez żadnych (przynajmniej wprost sformułowanych) ideologicznych założeń odpowiada intymnością na głos intymności $-\mathrm{z}$ wrażliwością i szacunkiem traktując najdrobniejsze ślady cudzego cierpienia, nie przekraczając granicy taktu i dyskrecji. Stara się utrzymać chwiejną równowagę między etyką i estetyką. Mimo iż stawia sobie zadanie karkołomne: śledzi ślady doświadczenia bólowego w tekstach poetyckich, które niejednokrotnie zdają się odległe od intymnych, osobistych wyznań - nie robi tego, szukając sensacji, łatwych analogii między biografią i poetyckim zapisem. Autorka woli raczej powiedzieć za mało niż o jedno słowo za dużo. Przyjmuje postawę etyczną, by tropiąc autorską estetykę, dotrzeć do tego, co ma charakter egzystencjalny, co poprzedza sztukę.

Książka Pietrych stanowi więc świadectwo zwrotu, jaki dokonał się w badaniach literaturoznawczych. Siłą takiego czytania nie jest już naukowy obiektywizm, pozbawiona osobistych emocji narracja umieszczająca autorski punkt widzenia na zewnątrz zaprojektowanych przez tekst literacki sytuacji komunikacyjnych, lecz osobiście zaangażowana perspektywa lektury, która nie rości sobie prawa do rozstrzygania tego, jak jest. Pietrych to uważna słuchaczka, wyczulona na cudze emocje, korzystająca ze swego filologicznego warsztatu w sposób nieapodyktyczny, z delikatnością i ostrożnością akuszerki, na której oczach rodzi się nowy sens.

Mamy zatem w przywołanej pracy do czynienia ze zbiorem zapisów siedmiu bardzo osobistych, intymnych wręcz spotkań. Ich bohaterami są kolejno: Aleksander Wat, Zbigniew Herbert, 
Miron Białoszewski, Stanisław Barańczak, Janusz Szuber, a także - jako autorzy pojedynczych wierszy - Julian Przyboś i Anna Świrszczyńska. Każdy z nich zostaje zaprezentowany jako człowiek nękany chorobą - każdy z nich w zupełnie odmienny sposób traktował to egzystencjalne doświadczenie.

Wat, poeta doctus, szukał w poezji ratunku przed zniszczeniem przez obezwładniający ból. Cierpienie jest tematem i substancją wielu jego wierszy. Tak właśnie dzieje się w utworze przywołanym w tytule książki Pietrych. Zacytowane pytanie to incipit jednego z Naszeptów magnetofonowych - nagrywanych przez niego nocami na taśmę magnetofonową, gdy ból związany z przewlekłą chorobą neurologiczną (zespół opuszkowy Wallenberga) nie pozwalał mu na pisanie. Spisane po jego śmierci przez żonę, Olę Watową, Naszepta... stanowią porażające świadectwo cierpienia, które prowokuje do postawienia pytania o jego sens i staje się eksplikacją najgłębiej skrytych źródeł tej poezji, związanych z relacją między pisaniem a doświadczeniem:

Co poezji po bólu? Poezja nie lazaret -

Obwieszcza wieszcz narodowy.

On ze słów najlonowych buduje wieżowce „rodnie powidoków” socjalistycznych ${ }^{\mathrm{I}}$.

To wiersz nasycony parodystycznymi aluzjami do Przybosiowego Widzenia katedry w Chartres. Jego autor jest tu obecny jako apologeta socjalistycznej utopii nowoczesnego miasta i pracy poety jako architekta słowa. Jest tu także zwolennikiem precyzyjnej konstrukcji poematu, w której każdy element musi być „produktem rzemiosła poetyckiego" ${ }^{\text {I9 }}$, efektem pracy wykonanej w języku, przetwarzającej wszystkie życiowe uczucia $\mathrm{w}$ doświadczenie estetyczne. Przybosiowy poemat ze światła, ze wzrokiem jako dominującym zmysłem kształtującym poetyckie widzenie, staje się kontrapunktem dla somatycznej, skoncentrowanej na doświadczeniu dotykowym, późnej poezji autora Czarnego świecidła. W wierszu Widzenie katedry w Chartres pojawiają się sformułowania: „rodnia gwiazd i barw” oraz „powidok słońca”, odsyłające do przetworzonego poetycko przeżycia, stwarzającego ze słów jedyną i niepowtarzalną sytuację liryczną, wolną od pozapoetyckich emocji autora, od autobiograficznych sugestii (mimo oczywistych zbieżności przeżyć autora i podmiotu lirycznego wiersza). Pytanie: „Co poezji po bólu?” jest więc

I8 A. Wat, ${ }^{* * *}$ Co poezji po bólu?..., w: Pisma zebrane, t. 1, Poezje, oprac.

A. Micińska, J. Zieliński, posłowie J. Zieliński, Warszawa 1997, s. 419.

I9 J. Przyboś, Idea rygoru, w: Linia i grwar, Kraków 1959, s. 13. 
w wierszu Wata rodzajem parafrazy głosu Przybosia, sfingowanym przytoczeniem.

Zarówno poezja Wata, jak i książka Pietrych okazują się $\mathrm{w}$ tej perspektywie odpowiedziami ${ }^{20}$. Dla Wata poezja wyrasta właśnie z doświadczenia bólu, a jednocześnie pełni funkcję terapeutyczną. Badaczka pokazuje, jak poeta - posługujący się repertuarem środków poetyckich - świadomie dystansuje się od nich, obnażając „tragiczną nieadekwatność estetycznych gestów wobec choroby i cierpienia" (s. 76), rekonstruuje heroiczny w swej wymowie wymiar dzieła, które powstało z bólu i pomimo bólu (s. 80). Opisanie go, ujarzmienie dzięki metaforze, symbolowi i innym zakorzenionym w śródziemnomorskiej kulturze strategiom tekstowym miałoby go intelektualnie $\mathrm{i}$ artystycznie okiełznać. Ocalenie - jak pokazuje Pietrych - pochodzi z wiary w szczególną moc poetyckiego słowa, którego symbolistyczna natura odsyła do rzeczywistości transcendentnej. Ale dla Wata, piszącego $\mathrm{z}$ najwyższym trudem $\mathrm{w}$ chwilach ulgi, ból staje się weryfikatorem poetyckiej prawdy. Idealistyczne projekty estetyczne „pieśniarza optymistyki” i jego własne nie wytrzymują próby cierpienia. W tej sytuacji bardzo znaczący staje się zamieszczony w książce Pietrych szkic o Róży - ostatnim wierszu Przybosia. Utwór ten, będąc „wysoce wyrafinowaną i wyestetyzowaną wypowiedzią poetycką" (s. 261), odsłania - zdaniem badaczki - zarazem egzystencjalny, najbardziej osobisty wymiar wypowiedzi. Czyżby była to niezamierzona, polemiczna odpowiedź na zarzuty Wata, którą dopisało życie?

Zupełnie inaczej rzecz wygląda w przypadku Herberta. Poeta empatyczny, traktujący współczucie jako wstępny warunek pisania poezji - nigdy nie ujawniał swoich cierpień. A zmagał się z nimi przez długie lata: najpierw ich źródłem była astma, potem zaś dodatkowo depresja, która niszczyła poetę, stawiając go wielokrotnie nad otchłanią. Wydobycie na jaw tych rzadko za życia autora podejmowanych wątków biograficznych rzuca nowe światło na wiele jego utworów. I choć dopiero w Epilogu burzy mamy do czynienia z prawdziwie osobistym tonem, to jednak rozprawa Pietrych także we wcześniejszej twórczości czytanej przez pryzmat życiowych doświadczeń odsłania nowe pokłady sensów, które uznać można za „pismo bólu”.

${ }^{20}$ Autorka nie wspomina jednak o intertekstualnych nawiązaniach do poematu Przybosia. Co ciekawe, na stronie tytułowej cytat ów pojawia się w tytule bez znaku zapytania. Ta drobna wydawnicza rozbieżność wydaje się nieprzypadkowa, gdyż zmienia modalność zdania w stwierdzenie znaczące „oto, co poezji po bólu". 
Spotkanie z cierpiącym Białoszewskim przebiega nieco inaczej. Jego dolegliwości gruźlicze, urologiczne, sercowe, a nawet prozaiczny ból zębów, były wszak przez samego poetę wielokrotnie tematyzowane. Czynił je przedmiotem żartów, oswajał stopniową utratę niezależności i grozę umierania przez czarny humor i groteskę. Opowieść o autorze Zawału, właśnie dlatego że on sam podsuwa swoim czytelnikom gotowy repertuar form i masek pod pozorem szczerości, wydaje się też stosunkowo najmniej odkrywcza. Badaczka powtarza twierdzenia znane historykom literatury. Okazuje się, że metoda empatii przestaje być funkcjonalna tam, gdzie ból i choroba znajdują się na powierzchni pisma ${ }^{21}$.

$\mathrm{Z}$ tego powodu też zupełnie niezwykły i bodaj najbardziej fascynujący jest rozdział poświęcony cierpieniu Barańczaka. Trudno bowiem powiedzieć, że jest to tylko opowieść o cierpieniu $\mathrm{w}$ jego poezji. Ten - znany z powściągliwości i samodyscypliny poeta, czyniący z tych cech element swego programu, protestujący „przeciwko poetyce ekspresjonistycznego czy «konfesyjnego» wypruwania sobie bebechów" ${ }^{22}$ - ani razu wprost nie wspomniał o swojej chorobie w jakimkolwiek wierszu. Jednak badaczka tropi w jego utworach ślady fizycznego cierpienia. Pokazuje, jak w milczeniu na temat zmagania z chorobą Parkinsona - którą zdiagnozowano u poety w 1986 r., która odbiera ciału sprawność, a umysłowi panowanie nad nim - skrywa się przejmująca historia człowieka usiłującego przeciwstawić poezję biologii i czyniącego z tej pierwszej schronienie przed chaosem, chorobą i cierpieniem, schronienie osłaniające prywatność przed wścibstwem i ciekawością żądnego sensacji świata.

Również w poezji Szubera - poety na wózku inwalidzkim daje o sobie znać nieuchronne uwikłanie we własną somatyczność, a także poczucie bezradności i nieadekwatności pojęciowych kategoryzacji wobec natury jaźni, która - spotęgowana dotkliwą słaboścą ciała - bezustannie daje znać o swojej osobności, izolującej podmiot od rozumianego w sposób metafizyczny tego, co najważniejsze.

Ostatnie dwa 4-stronicowe szkice dotyczą wspomnianego już wiersza Róża Przybosia oraz Jutro będą mnie krajać Świrsz-

${ }^{21} \mathrm{~W}$ dodatku aż czterokrotnie w tytule interpretowanego wiersza Białoszewskiego powtarza się literówka. Zamiast wiersza siulpet pojawia się siuplet, co, - ze względu na wagę przywiązywaną przez badaczkę do analizy językowej utworów - wydaje się błędem dość znaczącym. Podobnie jak w przypadku dramatu Osmędeusze, który zmieniony został w Osmadeuszy.

${ }_{22}$ S. Barańczak, „Poezja musi być wieczną czujnościa” [rozmowa z P. Wierzchosławskim], w: Zaufać nieufności. Osiem rozmów o sensie poezji 1990-1992, red. K. Biedrzycki, Kraków 1993, s. 60, cyt. za: K. Pietrych, op.cit., s. 187. 
czyńskiej. Oba zapisy poprzedzone zostały komentarzem, którego fragment warto przytoczyć, ponieważ doskonale obrazuje ich charakter:

odrębnie [...] chcę potraktować wiersze, które mają dla mnie znaczenie wyjątkowe. Każdy z nich, czytany po raz pierwszy, zatrzymał moją uwagę - niemal fizycznie uderzył i jak najdosłowniej ,zadziałał" słowami (siłą swej słownej ekspresji), zmuszając do przekroczenia granic tekstualności. Zobaczyłam twarz Innego i od tego widoku trudno już się było uwolnić. Ów ruch wiersza skierowany ku Innemu zobowiązywał do nieustannie ponawianych spotkań - do empatycznego współbycia. (s. 253)

Uwagi sformułowane po tym wprowadzeniu stanowią jednak świadectwo impasu, do jakiego prowadzić musi metoda "przekraczania granic tekstualności”. W notatkach z lektury brakuje głębszego, narracyjnego oddechu towarzyszącego wcześniejszym opowieściom o pięciu poetach. Jest za to potężna dawka emocji, które prowadzą do kategorycznych, lecz niepotwierdzonych dokładniejszą analizą wiersza konstatacji w rodzaju: „wyniesiona i ubóstwiona poezja okazuje się w sytuacji granicznej wszechmocna: koi ból, a nawet pozawala się od niego uwolnić” (s. 260) to o Przybosiu. Zamiast rzeczowej argumentacji wyprowadzonej z poetyki tekstów oraz autorskich stylistyk, Pietrych znajduje oparcie w filozoficznej perspektywie, którą nakłada na czytane wiersze. Komentując utwór Przybosia, w pewnym momencie traci z oczu znakowy charakter rzeczywistości poetyckiej, eksponując w zamian etyczny i osobiście odczuwany wymiar wezwania do współbycia ze starym, schorowanym poetą ${ }^{23}$. W przypadku Świrszczyńskiej dominuje Derridiańsko-Lévinasowska (sic!) perspektywa spotkania z tekstem-twarzą. W akcie empatycznej lektury udaje się „zobaczyć twarz cierpiącego poety i człowieka” (s. 275). Jej współbycie i współcierpienie zostaje zarejestrowane jako iluzja bezpośredniego obcowania: jako spotkanie z Drugim na płaszczyźnie etycznej. Nie jest to jednak w gruncie rzeczy ani trop Derridiański - bo autor Pisma i różnicy w tekście widzi zawsze tylko ślady obecności, której źródło jest niepochwyt-

23 Warto w tym miejscu wspomnieć o mistrzowskiej interpretacji motywu róży w poezji Przybosia autorstwa S. Balbusa. Zob. S. Balbus, Znaki ró́zy (Opoezji Juliana Przybosia), w: Od tematu do rematu. Przechadzki z Balcerzanem, red. T. Mizerkiewicz, A. Stankowska, Poznań 2007, s. 345-376. O „poetyckiej róży” z ostatniego wiersza Przybosia badacz pisze, że stanowi ona „niezwykłe poetyckie świadectwo aktywnego zaangażowania sztuki (i samego procesu twórczego) nawet w najbardziej graniczne, ostateczne egzystencjalne doświadczenia człowieka-artysty" (s. 376). 
ne, ani teologiczna relacja Lévinasa - która wymaga spotkania bezpośredniego, twarzą w twarz. Wyznanie: „zobaczyłam twarz Innego" jest subiektywnym odczuciem autorki, wobec którego pozostajemy bezradni.

Wszystkie te uwagi odnotowuję po to, by pokazać, jak niebezpieczną i trudną perspektywę obrała sobie autorka Co poezji po bólu... Powtórzmy: powołując się na patronów uważnego czytania, formułuje swój projekt lektury dociekliwej, ostrożnej, $\mathrm{z}$ uwagą wsłuchującej się nie tylko $\mathrm{w}$ to, co wyrażone, ale też przede wszystkim w to, co wymyka się wyrażeniu, co pozostaje między słowami, w przemilczeniu, w figurach dystansu ironii, micie, metaforze, parodii, humorze. Barańczak, Szuber czy Przyboś nie mówią wprost o swym cierpieniu, lecz swój ból kamuflują, pseudonimują, maskują - tak też dyskretnie i taktownie o tym doświadczeniu stara się mówić badaczka, zdejmując warstwy literackich konwencji, bandaże słów z pulsującego boleśnie doświadczenia ciała, które opresyjnie narzuca swe ograniczenia intelektowi, wyobraźni i inwencji twórczej poety. Mogłaby ona, podobnie jak Hélène Cixous, powiedzieć: „tekst uczy nas, że najtrudniejszą rzeczą jest osiągnięcie najskrajniejszej bliskości, danej jednak w taki sposób, by ustawicznie strzec się pułapki własnych projekcji czy identyfikacji. «Przy największej możliwej bliskości Inny musi pozostać obcy»” ${ }^{24}$. Czasami jednak zdarza się, że autorce nie udaje się przed tym skrajnym utożsamieniem ustrzec. Przykładem tego są dwa ostatnie - szalenie intensywne - spotkania, w których czytająca zdaje się tracić dystans do swoich bohaterów.

Tymczasem to, że dystans i empatia stanowią nieantagonistyczną parę, świadczą właśnie przewijające się przez książkę Pietrych bezcenne uwagi. Badaczka zajmuje się przecież komunikacyjnym wymiarem empatii w relacji czytelnik - autor. Podejmuje próbę empatycznej lektury poezji, w której „między widoczną a niewidoczną stroną poetyckiego obrazu" (s. 223) tropi ślady fizycznego cierpienia autorów. Jednocześnie zaś mówi o różnych sposobach budowania dystansu podmiotu wobec własnych cierpień. W przestrzeni literackiej dzieje się to za pośrednictwem formy: staje się ona przesłoną - raz dyskretnie, to znów ostentacyjnie ukrywającą najbardziej intymne dramaty egzystencji (s. 227). Podmiot „poprzez mówienie nie wprost, a za pomocą przenośni buduje dystans wobec własnego doświadczenia” (s. 93). Takie, właściwe tradycyjnej filologii, analityczne

${ }_{24}$ H. Cixous, Coming to Writing and Other Esseys, red. D. Jenson, wstęp S. Robin Suleiman, Cambridge 1991, s. 170-171, cyt. za: A. Łebkowska, op.cit., s. 33-34. 
podejście do tekstu jest konsekwencją przyjętej za Ricoeurem perspektywy hermeneutycznej. Badaczka pokazuje, że podmiot może mówić o swoim cierpieniu, tylko posługując się znakami, oddzielając w ten sposób od jaźni cierpienie, oddalając się od niego i oglądając owo cierpiące „ja” jako kogoś innego. Jednocześnie zaś dowodzi, że można i należy próbować dotrzeć poza tekst, interpretując go jako ślad współkonstytuujący doświadczenie.

Właśnie przez budowanie takiego stosunku do własnego bólu, który jest nie do wysłowienia, poeci są w stanie go zakomunikować. Niekoniecznie wprost, lecz przez rozmaite chwyty, łącznie z konsekwentnym milczeniem na jego temat (Barańczak), uobecniają w przestrzeni wiersza swoje doświadczenie choroby. W ten sposób sygnalizują dystans wobec własnej cielesności, która dyktuje sposób przeżywania, myślenia i pisania, mogą - przynajmniej w tekście - zapanować nad tym, co nimi włada. To podstawowa, terapeutyczna funkcja pisania. Stąd empatia jako narzędzie badawcze jest postawą, z której nieadekwatności trzeba zdawać sobie sprawę. Współczucie, współodczucie, wczucie - to tylko próby odtworzenia w sobie doświadczenia inności, którą - jeśli chcemy zachować jej niepowtarzalność, odrębność, inność właśnie - tak należy właśnie traktować: jako nie-do-pojęcia. Ponadto samo wymawianie niewysławialnego przeżycia bólowego czyni tę eksplikację nietożsamą z doświadczeniem.

Warto pamiętać o tym, że język zmienia strukturę doświadczenia - że do „prawdziwego”, pozajęzykowego przeżycia nie mamy dostępu, co badaczka wskazuje we wstępie. Zostają nam za to liczne zapośredniczenia, których przedziwny status polega na tym, że z jednej strony umożliwiają ujawnienie tego, co samo uniemożliwia wszelki dyskurs, z drugiej zaś - osłaniają źródłowe przeżycie dodatkowymi warstwami stylistycznych i formalnych wyborów. Podstawowe założenie przyjęte przez Pietrych mówi, że wszystkie te wybory nie oddalają ani nie zniekształcają tego, co - jak możemy przypuszczać - było pierwotnym impulsem pisania (a co znajduje się w gestii lekarzy i psychologów, nie literaturoznawców), lecz są częścią składową doświadczenia, poza którym nie jest ono niczym więcej niż chaotyczną magmą impulsów docierających do podmiotu.

Taka perspektywa zawiera w sobie moment decyzji etycznej. Musimy bowiem przyjąć z pełnym zaufaniem założenie dobrej wiary po stronie autora, które wyklucza możliwość udawania, ironiczności czy gry. Wszystkie te wybory formalne są pochodną wcześniej przyjętego warunku szczerości i prawdziwości doświadczenia bólu (potwierdzonego biografią), doznania trak- 
towanego nie jako literacki topos, temat czy motyw, lecz jako pierwotne wobec tekstu doświadczenie somatyczne. W tym sensie owo pierwotne doświadczenie - fizyczny ból - jest nie do wysłowienia. Badaczka opisująca doświadczenia skrajne, z natury swej niewyrażalne zwraca uwagę właśnie na tę niezwykłą właściwość pisma bólu. Wskazuje na to, że posługiwanie się ironią, rozmaitymi odmianami stylizacji, groteską, humorem, a także metaforą i innymi środkami retorycznymi nie tylko eksponuje „nieadekwatność konwencjonalnego języka w doświadczeniu cierpienia” (s. 93), ale także pokazuje, jak poezja uobecnia to, co nazwane wprost, wymyka się i pozostaje poza zasięgiem zarówno wyrażenia, jak i empatycznego ogarnięcia.

Literacka forma ujawnia w tym przypadku swą podwójną funkcję; po pierwsze, pozwala na przekazanie tego, co niewyrażalne wprost, po drugie jednak - może być synonimem sztuki „zdystansowanej, chłodnej, doskonale harmonijnej, ale zimnej i pozbawionej daru empatii" (s. 112). Reprezentantem takiej postawy staje się Apollo z wiersza Herberta Apollo i Marsjasz. Grecki bóg uosabia zdystansowany, a to znaczy w tym wypadku nieludzki model sztuki (apollińskiej), która - metaforyzując i uwznioślając - przesłania to, co najistotniejsze: prawdę o istocie cierpienia. Taki, ambiwalentny, jest charakter formy. Jako konwencjonalne i powtarzalne forma jest tym, co dystansuje wobec ludzkich emocji. Zarazem jednak forma w ogóle umożliwia ich ujawnienie przez sztukę. Po to, by dać wyraz uczuciom, trzeba nadać im jakiś kształt, czyli wyraz. Wiadomo, że każdy sposób ujawniania tego, co pierwotniejsze wobec wyrażenia, jest już mediacją. Środki artystycznego wyrazu stają się w połączeniu z modalnością konkretnego teksu znakiem tego, co wymyka się wyrażeniu. Prawda doświadczenia, jak wszelkie osadzone w rzeczywistości zdarzenia i osoby, nigdy nie jest dana wprost. Także wszelki przekaz dokumentarny skazany jest na posługiwanie się środkami artystycznego wyrazu, jedynie bowiem zapośredniczając to, co odnosi się do doświadczenia, jest w stanie w ogóle doświadczenie ujawnić. Biorąc zaś pod uwagę fakt, że poezja jest kwintesencją literackości, mamy do czynienia z sytuacją dość szczególną: poeci posługują się świadomie środkami należącymi do repertuaru chwytów poetyckich, by dać wyraz temu, co nie chce i nie może zostać za ich pomocą przekazane, co - mówiąc inaczej - wymyka się reprezentacji. Stąd wielorakie strategie, jakie obierają poeci, żeby uobecnić ból.

Należy do nich między innymi liryka roli, która Herbertowi pozwala wydobyć rozmaite „stopnie dystansu pomiędzy autorem wewnętrznym a podmiotem mówiącym” (s. 122). Podobnie 
działa też ironia, która, określona trafnie „strategią dystansu” (s. 246), buduje rozmaite jego odcienie wobec poglądów i sytuacji przedstawianych w tej poezji. Na pytanie „Czy ironia może ocalić przed chorobą?”, badaczka odpowiada: „Raczej pozwala na budowanie do niej dystansu, na odnalezienie takiego tonu mówienia, który byłby «barwą ochronną» doświadczanego «ja»" (s. 246). Z kolei Białoszewski swój dystans wobec choroby buduje, posługując się humorem, niekiedy czarnym. Tego typu ujęcie rzeczywistości okazuje się - podobnie jak ironia skuteczną strategią obronną. Autor Obo oswaja powagę i grozę przez estetykę groteski oraz rozmaite pastiszowo-parodystyczne zabiegi stylizacyjne. Także sposoby unaoczniania relacji intertekstualnych, będące kwestią formy, służą ujawnieniu określonej świadomości. W przypadku Szubera badaczka pokazuje, że „dystans, jaki poprzez intertekstualny chwyt [poeta] buduje, ma być podkreśleniem naiwności własnego gestu" (s. 228). Jednocześnie zaś taka świadoma „terapia stylizacją” skazana jest od początku na klęskę, „podszyta jest bowiem ironiczną samoświadomością autora, budującą dystans wobec podejmowanych przez niego zabiegów” (s. 229).

Te jawne gesty $\mathrm{w}$ obrębie użytych środków zawsze mają oczywiście nacechowanie semantyczne. Przypominają swoim mechanizmem retoryczną ironię, którą Paul de Man definiował jako permanentną parabazę: gest unieważniający wiarygodność każdej wypowiedzi i dający dotkliwe poczucie, że za językowymi, stylizacyjnymi, narracyjnymi, retorycznymi maskami nie skrywa się żadna prawdziwa twarz. Według Pietrych natomiast wszelkie gesty dystansujące autorski podmiot wobec własnych wypowiedzi podkreślają intymność, samotność i szczerość „ja”, które - właśnie dlatego, że nie utożsamia się z żadną własną wypowiedzią - potwierdza własną przewagę nad formą. Byłaby to zatem strategia romantyczna, kontynuująca myślenie o silnym, mimo fizycznej słabości, podmiocie, zdolnym przez zdecydowany podmiototwórczy gest kreacji zapanować nad bezładem i chaosem języka, a także nad słabością własnego ciała. Te metody obrony pozwalają także nękanemu fizycznym cierpieniem poecie eksterioryzować ból, umieścić go na zewnątrz swego „ja”, które integruje się przez świadome posłużenie się formą. Tak dzieje się - zdaniem Pietrych - w przypadku poezji Barańczaka. Konsekwentnie pomija on temat wieloletniej choroby i związanych z nią dolegliwości. Wszelkie wypowiedzi na temat bólu, umierania i śmierci przenosi $\mathrm{w}$ obszar uniwersum ludzkich doświadczeń tak, że każdy z czytających może te sformułowania odnieść przede wszystkim do siebie, bez konieczności 
przywoływania wiedzy o podmiocie autorskim. W ten sposób „stylizacyjny dystans”, podobnie zresztą jak wszystkie strategie dystansu, pozwala ocalić tożsamościowy projekt, choć nie daje pozytywnej przeciwwagi dla somatycznej opresji. Jak zauważa badaczka w podsumowaniu swych rozważań, pamiętać trzeba, że „poetycki sposób mówienia [...] obcość [mowy] nie tyle nawet oswaja, co ujawnia” (s. 273). Dystans staje się strategia poetyckiego istnienia, chociaż nie gwarantuje przywrócenia bezpośredniości:

Mityzacja czy uniwersalizacja to kwestia formy, czyli takiego sposobu wyrażania, który opiera się na dystansie, racjonalności, precyzji. To sprzeciw wobec chaosu świata, historii, biologii. Formą można wyrazić protest wobec śmierci bliskiej osoby, formą można nie zgodzić się na własne doświadczenie. (s. 210)

Dystans stanowi tu przede wszystkim wyraz postawy estetycznej i sposób artystycznego przekazu emocji. Zastanawiające, a przez badaczkę nierozstrzygnięte jednoznacznie, pozostaje pytanie o to, co decyduje, że raz forma traktowana jest jako niezbędny element umożliwiający ujawnienie głębi i złożoności podmiotowego doświadczenia, kiedy indziej zaś - jest tym, co buduje dystans emocjonalny, potęgujący sztuczność i nieadekwatność słów. Reprezentantem tej drugiej postawy jest przywoływany wcześniej Apollo z wiersza Herberta. Wydaje się, że za każdym razem jest to kwestia rozgrywana w obrębie konkretnego tekstu. Skutek okazuje się rodzajem jednorazowej modalności, która stanowi o idiomatyczności, niepowtarzalności wiersza, budowanego za pomocą powtarzalnych środków. Niepowtarzalne ujawnia się w momencie zetknięcia czytelnika z tekstem, a za pośrednictwem utworu - z osobowym autorem, który pozostawił w tekście własną sygnaturę.

Jeśli coś budzi w konsekwentnym wywodzie badaczki moje wątpliwości, to dotyczą one zrównania problemów z reprezentacją (wyrażalnością, przedstawialnością) ekstremalnego doświadczenia bólu z problemem reprezentacji Shoah (s. 23-26). Rozumiem metodologiczne motywy, jakimi kierowała się autor$\mathrm{ka}-\mathrm{w}$ jednym i drugim przypadku mamy do czynienia z niewyrażalnym. Natury tych dwóch niewyrażalności - bólu i Holocaustu - nie sposób jednak porównywać. Dlatego niestosowne jest zestawienie indywidualnego, podmiotowego doświadczenia zmagania się z werbalizacją cierpienia, które jednakże nie jest wyjątkowe i w tym sensie niewyobrażalne (każdy z bohaterów książki cierpi z powodu konkretnej choroby), z wydarzeniem 
Holocaustu, którego istotą jest absolutne odpodmiotowienie ofiar i pozbawienie ich prawa głosu. Piszę o tym, ponieważ w świetle lektury etycznej i aksjologicznej, jaką proponuje nam autorka, zobligowani jesteśmy do takiego właśnie - pogłębionego etycznie - umiaru w stosowaniu zbyt łatwych, choć narzucających się, analogii.

Doświadczenie Shoah pozostaje wydarzeniem osobnym, jak osobna i samotna pozostawała zbiorowość jego milczących ofiar. Etyczny dylemat tych, którzy próbują przedstawić niewyobrażalne zło, jakie działo się w konkretnym miejscu i czasie, wiąże się $\mathrm{z}$ faktem, że ono samo zakwestionowało prawomocność wszelkiego wyrażania. I taki też - osobny, nieporównywalny z niczym - powinien być status badań nad Holocaustem. Czyż może być bowiem większa różnica niż dzieląca milczącą anonimowość śmierci milionów ludzi od indywidualnego wymiaru jednostkowego cierpienia inicjującego pisanie poezji? Poeci zawsze mają wybór: między milczeniem a mową na temat własnego cierpienia. Jeśli decydują się mówić, posługują się z własnej woli językiem, który staje się częścią ich przeżycia.

Jest jeszcze jedna wątpliwość, która nie daje mi spokoju. Zastanawiam się mianowicie, czy - zgodnie z deklaracją autor$\mathrm{ki}-\mathrm{w}$ istocie mamy do czynienia $\mathrm{z}$ postulowanym przez $\mathrm{Mi}-$ chała Pawła Markowskiego nowym językiem, który byłby „obcy zarówno nowoczesnej tezie o całkowitej przedstawialności ciała, jak i ponowoczesnej tezie o jego nieprzedstawialności" ${ }^{25}$. Kiedy sięgniemy do książki Julii Kristevy Potęga obrzydzenia. Esej o westręcie, trafimy na takie oto słowa:

Ból jako miejsce podmiotu. Tam, gdzie się wydarza, gdzie się odróżnia od chaosu. Rozżarzona, nieznośna granica między wnętrzem a zewnętrzem, „ja” a innym. Pierwsza odsłona, nietrwała: „ból”, „lęk”, słowa krańcowe skierowane na krawędź, gdzie sens kieruje się na inny sens, „to, co intymne” na „nerwy”. Byt jako niedostatek ${ }^{26}$.

Podobne sformułowania pokazują z całą mocą, że Pietrych rysuje perspektywę, w której ból należy do przestrzeni sacrum, do sfery człowieczeństwa, w której jest wartością. Nawet jeśli nie dzieje się tak w wymiarze egzystencji autorów, to uświęcenie dokonuje się w empatycznej przestrzeni lektury proponowanej przez autorkę. Książka Co poezji po bólu... pokazuje, jak podmiot

25 M.P. Markowski, Nowoczesność: ciało niedoświadczone, w: Nowoczesność jako doświadczenie, red. R. Nycz, A. Zeidler-Janiszewska, Kraków 2006, s. 90.

${ }^{26}$ J. Kristeva, Potęga obrzydzenia. Esej o westręcie, przeł. M. Falski, Kraków 2007, s. 131. 
cierpiący radzi sobie z własnym bólem, jak nie daje mu się zniszczyć, jak obezwładniające cierpienie odcina się od swego najgłębszego „ja”, ocalając tym samym owo „ja”, które zwycięsko wychodzi z opresji ciała. I jak, mimo wszystko, ból uszlachetnia. Tymczasem wystarczy zmienić perspektywę, by ujrzeć ból stanowiący drzwi do piekła, związany ze wstrętem i grozą skatologii. Gdyby w polskiej poezji szukać tego rodzaju krańcowych doświadczeń, wskazać by trzeba Rafała Wojaczka, Stanisława Grochowiaka, a przede wszystkim Kazimierza Ratonia, który w nielicznych pozostawionych po sobie zapisach zawarł porażające świadectwo wstrętu i pogardy do siebie:

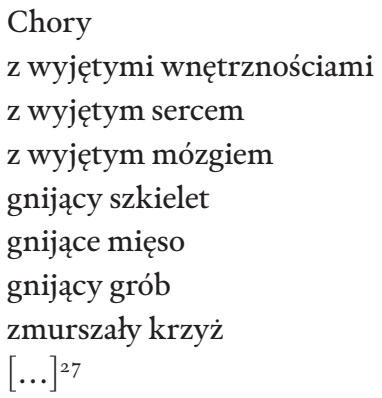

$\mathrm{Na}$ pominiętym przez badaczkę drugim biegunie bólowego pisma znajdujemy więc obrazy cierpienia „oddychającego mięsa” - cierpienia istoty, która sama siebie nie traktuje już jak człowieka i która żywcem umiera przez wiele lat na gruźlicę mózgu, szukając $\mathrm{w}$ alkoholu uśmierzenia bólu nie tylko fizycznego, lecz także tego, o którym Pietrych nie pisze prawie wcale: bólu bezsensownego istnienia. Ratoń był dla tych, którzy go znali, postacią odrażającą - żywym trupem snującym się po ulicach, konającym na raty, budzącym odrazę, a w najlepszym razie politowanie. Jego poezja stanowi wyróżniający się w polskiej literaturze zapis, do którego doskonałym komentarzem byłyby słowa Kristevy:

W świecie, gdzie Inny się stoczył, wysiłek estetyczny - zejście z fundamentów symbolicznej budowli - polega na ponownym wyznaczeniu kruchych granic bytu mówiącego, jak najbliżej kolebki, tego „źródła” bez dna, którym jest wyparcie zwane pierwotnym. W tym doświadczeniu, mimo wszystko kontrolowanym teraz przez Innego, „podmiot” i „przedmiot” odpychają się, konfrontują ze

${ }^{27}$ K. Ratoń, ${ }^{* * *}$ Chory/ z wyjętymi wnętrznościami..., w: Poezje, oprac. J.Z. Brudnicki, Warszawa 2002, s. 211. 
sobą, upadają i zaczynają od nowa - nierozdzielne, zarażone, skazane, na granicy tego, co można przyswoić, tego, co można pomyśleć: wstrętne ${ }^{28}$.

W doborze swoich bohaterów autorka kierowała się oczywiście własną wrażliwością i upodobaniami. Do selektywnego, subiektywnego doboru zastrzegła sobie prawo. Znaczące jest jednak to, że w poezji, którą czyta, nie ma skatologicznych obrazów cierpienia, chorób budzących wstręt, obrzydzenie, takich, którym patronuje w europejskiej literaturze Louis Ferdinand Céline i które opisywała językiem psychoanalizy Kristeva. W tym sensie Pietrych pozostaje nadal w paradygmacie nowoczesnym, w estetyce wzniosłości, jej somatoestetyka jest przede wszystkim estetyką budowaną na wierze, będącej najgłębiej ukrytym, a zarazem najważniejszym jej założeniem: że ból jako doświadczenie graniczne egzystencji jest dla tej egzystencji wartością, choćby negatywną. Mimo krańcowych stanów cierpiącego podmiotu ani przez chwilę nie traci on wiary w sensotwórczą wartość kodów kultury. Tak oto pozostajemy na obszarze starego języka, w którym humanizm stanowi wartość niezachwianą, obowiązuje kodeks etyczny, a cierpienie czyni lepszym zarówno cierpiącego, jak i pochylającego się nad nim.

Książka Pietrych wpisuje się w nowoczesną tradycję wyparcia tego, co wstrętne. Potwierdza, że „literatura współczesna w swych niezliczonych odmianach, kiedy przybiera postać wreszcie możliwego języka owej niemożliwości, czyli podmiotowości bądź nieprzedmiotowości, proponuje w gruncie rzeczy sublimację wstrętu" ${ }^{29}$. O ile jednak Kristeva mówi o sublimacji wstrętu, o tyle Pietrych sublimuje ból: sytuuje go w samym centrum podmiotowej i społecznej tożsamości. Książka pozostawia po sobie dziwne wrażenie, że ból otwiera tego, kto cierpi. Tymczasem w motcie zamieszczonym na początku książki pojawiają się słowa Witolda Gombrowicza, które jasno pokazują, że ból „jest samą podstawą rzeczywistości”, zamyka i wyzwala w cierpiącym solipsystyczną postawę autoteliczną: jest tylko cierpiące ciało i nic poza nim. Pozostaje zatem tylko kwestia wiary autorki w to, że empatyczna lektura buduje „przestrzeń lekturowej bliskości” (s. 35).

Próba spojrzenia na literaturę jako współbycie w cierpieniu jest idealistyczna, zaś przekonanie o tym, że sporządzenie „katalogu najdotkliwiej fizycznym cierpieniem naznaczonych

\footnotetext{
${ }^{28}$ J. Kristeva, op.cit., s. 22.

29 Ibidem, s. 29-30.
} 
poetów polskich XX wieku" (s. 46) pozbawiłoby jej bohaterów wyjątkowości Innego, uniemożliwiając z racji literaturoznawczej skrupulatności rozmowę $\mathrm{z}$ autorem, wydaje mi się tezą mocno naciąganą. Jeśli zatem estetycznym wyborom autorki trudno zarzucić brak konsekwencji - można bowiem odnieść wrażenie, że opisuje ona w swej książce poetów o podobnej do własnej wrażliwości, którzy na różne sposoby potwierdzają słuszność pobrzmiewającej w tytule tezy, że poezji ból jest potrzebny - to jako historykowi literatury i badaczce chciałoby się zadać pytanie o ów wymowny i znaczący brak: wyparcie wstrętnego (nieetycznego?), wypchnięcie poza nawias badawczej świadomości. Bez wątpienia jest to jednak temat na zupełnie inną opowieść, niemieszczącą się w zakreślonym przez Pietych horyzoncie empatycznych przestrzeni lektury.

\section{ELŻBIETA WINIECKA}

\section{Otherness that deserves to be protected. Empathy built upon distance}

The article is a review of Krystyna Pietrych's book Co poezji po bolu. Empatyczne przestrzenie lektury (Łódż 2009) (What good pain and suffering bring in poetry. Emphatic dimensions of reading]. Since the reviewed book presents a bold and, to a large extent, novel approach to personalistic reading - based on a subjective, compassionate experience of an encounter with uncognizable and unreductible otherness of tormented man-poet, the reviewer focuses on the issues viewed as the most important for the method of emphatic reading adopted by the author. E. Winiecka analyses aesthetical and epistemological, as well as axiological possibilities and risks that emphatic criticism opens up for reexamination. Formulates her own opinion on the analytical method used by K. Pietrych in examining poetry, which is a recording of one's mind in agony and suffering experienced by seven authors: Aleksander Wat, Zbigniew Herbert, Miron Białoszewski, Stanisław Barańczak, Janusz Szuber, as well as Julian Przyboś and Anna Swirszczyńska. Outlines the methodological perspectives of the discussed work that traces the stages in the formation of literary depiction and representation of suffering. The text is also an attempt at defining and indicating the cognitive perspectives of emphatic criticism.

ELŻBIETA WiNIECKA - dr, adiunkt w Zakładzie Literatury i Kultury Nowoczesnej Instytutu Filologii Polskiej UAM. Autorka książki Białoszeweski sylleptyczny (2006). Publikowała m.in. w „Pamiętniku Literackim”, „Tekstach Drugich” i „Przestrzeniach Teorii”.

e-mail: e.winiecka@wp.pl 
